\title{
Cyberloafing Among University Students
}

\author{
Fezile Ozdamli ${ }^{1,3}$, Erinc Ercag ${ }^{2}$ \\ ${ }^{1}$ Near East University, Department of Computer Information Systems, Cyprus \\ ${ }^{2}$ University of Kyrenia, Department of Computer Education and Instructional Technology, Kyrenia, Cyprus \\ ${ }^{3}$ Computer Information Systems Research and Technology Centre, Near East University, 99138 Cyprus
}

\begin{abstract}
Misuse or abuse of digital media can create negativities such as internet addiction, netlessphobia, cyberbullying, or cyberloafing. Cyber loafing is known as the use of employees in a workplace for non-work activities during working hours. This study aims to examine the cyberloafing levels of students studying in the Turkish Republic of Northern Cyprus. In this study, a descriptive survey model was used. The working group is composed of 150 students who study in the TRNC. "The Smart Phone Cyberloafing Scale in Classes" (SPCSC) developed by Polat (2018) was used as the data collection tool in the study. In the analysis of the data; $f, \%$, mean, and t-test analysis were used. According to the obtained results of the study, students sometimes do cyberloafing on their mobile devices during class. The implications for educators, parents, and teachers are discussed.
\end{abstract}

Keywords - Cyberloafing, students, smartphone.

\section{Introduction}

It has been scientifically proven that technology has many advantages in learning environments. Tapscott (2009) states that if the concepts of the internet and education are mentioned together, it is mentioned that contemporary education is talked about and that the internet is already an element of education in

DOI: $10.18421 /$ TEM101-53

https://doi.org/10.18421/TEM101-53

Corresponding author: Fezile Ozdamli, Near East University, Department of Computer

Information Systems, Cyprus.

Email: fezile.ozdamli@neu.edu.tr

Received: 25 December 2020.

Revised: 04 February 2021.

Accepted: 10 February 2021.

Published: 27 February 2021.

(cc) BY-Nc-ND (C) 2021 Fezile Ozdamli \& Erinc Ercag; published by UIKTEN. This work is licensed under the Creative Commons Attribution-NonCommercial-NoDerivs 4.0 License.

The article is published with Open Access at www.temjournal.com developed countries [1], [26]. However, misuse or abuse of digital media can create negativities such as internet addiction, netlessphobia, cyberbullying, or cyberloafing. Also, it is stated by researchers that the use of overuse smartphones of the young generation creates social, family, and academic problems [2]. Cyber loafing is known as the use of employees in a workplace for non-work activities during working hours. Due to the continuous advances in online communication opportunities and mobile technologies, cyberloafing can rise and emerge as a common way of wasting time during the work process. Askew et al. (2014) state that the internet enables employees to be more productive than ever before, but also offers the opportunity to escape from work [3].

Anandarajan et al. (2004) stated that there are four types of cyberloafing: entertainment, harmful, personal learning, and indeterminate [4]. Cyber loafing in the literature is presented in the following statements. It is seen that it is defined with different concepts such as internet deviance, problematic internet use, internet addiction, non-work-related computing, cyberslacking, cyberloafing, on-line loafing, personal web usage at work, internet dependency [5], [6]. Recent research on cyberloafing has shown that this can have some unexpected positive consequences. Mercado, Giordano, and Dichert (2017) stated in their meta-analytical study that cyberloafing does not have a negative effect, while Lim and Chen (2012) stated that cyberloafing improves the mood of individuals and positively affects employees' loyalty [7]. Cyberloafing is carried out not only at workplaces but also by teachers and students in educational institutions. Besides, even though phones were designed as an invention for speech, they have had many functions today. Smartphones appeal to people of all ages and all individuals use them for many operations. With the mobile feature of smartphones, it has become very common for students like all individuals. Researchers in the field of education are constantly looking for ways to improve learning processes for students, so many studies focus on how tools improve students' pedagogical experience [8]. However, it increases in cases such as nomophobia, addiction, cyberloafing caused by the use of smartphones [2]. 
Lim defined Cyberloafing as surfing the internet or using time inefficiently by watching videos during the lesson [1]. On the other hand, Kalayc1 explained cyberloafing as the behavior of students spending time on the internet for activities not related to the lesson [9]. In a study conducted to examine the relationship between pre-service teachers' creativity and cyberloafing, it was stated that there was a positive significant relationship [10]. Classes and work environments differ in terms of organization, employee and student rights, economic situation, communication style [11]. In a study conducted by Gökçearslan, Ulusoy, and Şahin (2018) with 885 students to examine the relationships between smartphone addiction, cyberloafing and stress, it is stated that stress and cyberloafing have an effect on each other [2]. Researchers stated that individuals use mobile devices to reduce their stress levels. Studies have shown that the participation of employees in online activities as a leisure activity helps them cope with work stress and concentrate more on future jobs [12],[13],[14],[15].

In a study conducted in 2006, researchers worked with people who were both teaching and continuing their master's degree, and when they checked the delivery dates and times of the projects they took in their graduate courses, it was determined that $51 \%$ of the teachers sent them during their class hours [16]. Garett and Danziger (2008), on the other hand, use the internet immediately when students are bored with the lesson or when they want to learn something when they examine the cyberloafing situation of students. In the research, it can be said that the students mostly watch and share videos, add photos, and make comments [17]. In the qualitative study carried out by Ergün and Altun (2012), students' views on cyberloafing were examined. According to the results obtained by the researchers, the majority of the students stated that they spend time on the internet outside the task assigned to them and that their friends also exhibit the same behavior [18]. As a result of the cyberloafing study of high school students conducted by Gezgin, Arslantaş, and Şumuer (2018), it was stated that students who use smartphones during their lessons have higher levels of cyberloafing compared to students who use computers [19]. In the study conducted by Keser, Kavuk, and Numanoğlu (2016), the relationship between internet addiction and cyberloafing was examined. According to the researchers obtained from the study, while the internet addiction levels of the students increase, the cyberloafing behaviors also increase [20]. In another study, the reasons for the cyberloafing of university students were investigated and it was determined that the biggest reason was their reluctance to learn. In the same study, other reasons were given to receive a notification on the mobile phone and the desire to be in communication and to have more fun time [21]. In a different study by Korucu and Kara (2019), it was determined that there is a significant relationship between the cyber loneliness levels and cyberloafing levels of university students during the course [22]. However, there is no study in the literature to determine the cyberloafing status of students studying in the Turkish Republic of Northern Cyprus. So, this study aims to examine the cyberloafing levels of students studying in the Turkish Republic of Northern Cyprus. The following questions were organized based on this goal:

- For what purposes do students use the smartphone?

- What are the levels of students on cyberloafing?

- Is the cyberloafing status of female and male students changing?

\section{Method}

In this study, a descriptive survey model was used. The working group is composed of 150 students who study in the TRNC. The return rate was $96 \%$ and 144 usable questionnaires were available for analysis.

Table 1. Students' demographic characteristics

\begin{tabular}{llcc}
\hline & & F & $\%$ \\
\hline \multirow{2}{*}{ Gender } & Female & 92 & 63.9 \\
& Male & 52 & 36.1 \\
\hline \multirow{2}{*}{ Daily } & Less than one hour & 4 & 2.8 \\
smartphone & 1-2 hours & 15 & 10.4 \\
\multirow{2}{*}{ usage } & 3-4 hours & 61 & 42.4 \\
& More than 5 hours & 64 & 44.4 \\
\hline
\end{tabular}

$53.8 \%$ of the students who participate in the research are females. The youngest of the students participating in the study is 18 years old and the oldest is 40 years old. The average age of the students was calculated as 22 . When the daily smartphone usage duration of the participants is examined, it is seen that the majority of the students use smartphones more than 3 hours a day.

\section{Instruments and Procedure}

"The Smart Phone Cyberloafing Scale in Classes" (SPCSC) developed by Polat (2018) was used as the data collection tool in the study. There are 16 items in the developed questionnaire and it is a 6-point Likert type. The scale consists of 3 sub-dimensions: "Browsing-related cyberloafing", "Entertainment cyberloafing" and "Interactive cyberloafing". In the study in which the data collection tool was developed, Cronbach Alpha's internal consistency coefficient was stated as 0.75 [23]. In this study, the Cronbach Alpha internal consistency coefficient was calculated as 0.89 . According to this finding, it can be said that the data are reliable. While evaluating the expressions in the data collection tool, the following limits were taken into account: 
Table 2. Point ranges

\begin{tabular}{lc}
\hline \multicolumn{1}{c}{ Option } & Ranges \\
\hline Never & $1.00-1.83$ \\
Rarely & $1.84-2.66$ \\
Sometimes & $2.67-3.49$ \\
Often & $3.50-4.32$ \\
Most of the time & $4.33-5.15$ \\
Always & $5.16-6.00$ \\
\hline
\end{tabular}

SPSS software, which is a statistical package program, was used in the analysis of the data obtained by taking the opinions of statisticians. In the analysis of the data; f, \%, mean, and t-test analysis were used and the level of significance was determined as .05 .

\section{Results}

\section{Students' smartphone usage purposes}

The frequency test was used to determine the reasons for the students participating in the study to use smartphones. The findings obtained are given in the Table below:

Table 3. The main reasons students use a smartphone

\begin{tabular}{lcc}
\hline Reason & f & \% \\
\hline Search & 129 & 89.6 \\
Messaging & 129 & 89.6 \\
Social networking & 124 & 86.1 \\
Listen to music & 121 & 84.0 \\
Homework and & 119 & 82.6 \\
research & 98 & 68.1 \\
News & 97 & 67.4 \\
Video & 92 & 63.9 \\
Shopping & 82 & 56.9 \\
Surfing the internet & 69 & 47.9 \\
Play games & 62 & 43.1 \\
Data storage & 55 & 38.2 \\
Mobile learning & 28 & 19.4 \\
Market and finance & 3 & 2.1 \\
Other &
\end{tabular}

As seen in Table 3, students mostly use the smartphone for making calls, texting, using social networking sites, listening to music, and homeworkresearch. In the study conducted by Minaz and Bozkurt (2017), similar to these findings, it is seen that the purpose of using the smartphone is primarily social media use and making calls [24].

\section{Cyberloafing Levels of Students}

It is thought that examining the cyberloafing situations of the students will contribute to the educators about which measures they will take. In this context, the smartphone cyberloafing in classes data collection tool prepared by Polat was applied to the students. Students were asked to choose the appropriate expression for them. The cyberloafing status of the students was determined and interpreted by calculating the mean and standard deviations with the obtained data. Findings obtained from the analysis are presented in Table 4.

Table 4. Findings regarding students' Cyberloafing status

\begin{tabular}{lcc}
\hline \multicolumn{1}{c}{ Browsing-related cyberloafing } & $\mathbf{X}$ & $\mathbf{S}$ \\
\hline $\begin{array}{l}\text { I download non-course related } \\
\text { information from my smartphone } \\
\text { during lessons. }\end{array}$ & 2.3403 & 1.33884 \\
\hline $\begin{array}{l}\text { I browse breaking news websites on } \\
\text { my smartphone during lessons. }\end{array}$ & 2.8611 & 1.52192 \\
\hline $\begin{array}{l}\text { I chat with other people on my } \\
\text { smartphone during lessons. }\end{array}$ & 2.9583 & 1.55494 \\
\hline $\begin{array}{l}\text { I instantly send messages to other } \\
\text { people on my smartphone, through } \\
\begin{array}{l}\text { Whatsapp, Messenger, and similar } \\
\text { applications. }\end{array}\end{array}$ & 3.1528 & 1.54340 \\
\hline $\begin{array}{l}\text { I send messages from my smartphone } \\
\text { to people who are not related to the } \\
\text { lesson. }\end{array}$ & 2.7361 & 1.43379 \\
\hline $\begin{array}{l}\text { I use the internet in lessons to learn } \\
\text { additional information about the lesson } \\
\text { from my smartphone. }\end{array}$ & 3.2917 & 1.52313 \\
\hline $\begin{array}{l}\text { I browse non-course related websites } \\
\text { on my smartphone during lessons. }\end{array}$ & 2.6597 & 1.48730 \\
\hline General & $\mathbf{2 . 8 5 7 1}$ & $\mathbf{1 . 1 1 2 8 7}$ \\
\hline
\end{tabular}

It has been determined that the university students participating in the study spend their time browsing their cell phones "sometimes" in their classroom environments. Also, it was determined that the students sometimes use the internet to learn additional information about the course from my smartphone.

However, the students stated that they sometimes use online instant messaging applications with their friends during the lesson. The students stated that they rarely downloaded information not related to the lesson from their smartphones during the lesson. These results show us that students sometimes use it for screening purposes other than the course. 
Table 5. Results regarding students' Cyberloafing status

\begin{tabular}{lcc}
\hline \multicolumn{1}{c}{ Interactive cyberloafing } & $\mathbf{X}$ & $\mathbf{S}$ \\
\hline $\begin{array}{l}\text { I shop online to buy personal items } \\
\text { during classes. }\end{array}$ & 2.3611 & 1.37211 \\
\hline $\begin{array}{l}\text { I check my e-mails from my phone } \\
\text { during classes. }\end{array}$ & 2.2917 & 1.19366 \\
\hline $\begin{array}{l}\text { I browse websites related to my } \\
\text { career from my smartphone in } \\
\text { lessons. }\end{array}$ & 2.5347 & 1.48613 \\
\hline $\begin{array}{l}\text { I send personal e-mails from my } \\
\text { smartphone during lessons. }\end{array}$ & 2.1319 & 1.30757 \\
\hline $\begin{array}{l}\text { I browse websites related to } \\
\text { entertainment (cinema, theater, } \\
\text { concert, etc.) on my smartphone } \\
\text { during lessons. }\end{array}$ & 2.8750 & 1.47176 \\
\hline $\begin{array}{l}\text { During lessons, I receive emails from } \\
\text { my smartphone that are not related to } \\
\text { the lesson. }\end{array}$ & 2.5903 & 1.52560 \\
\hline \begin{tabular}{l} 
General \\
\hline
\end{tabular} & $\mathbf{2 . 4 6 4 1}$ & $\mathbf{1 . 0 2 8 7 6}$ \\
\hline
\end{tabular}

According to the results obtained from the analysis, it was determined that university students rarely engage in cyberloafing for interaction purposes during the lessons. "I get e-mails from my smartphone during lessons that are not related to the lesson." It is seen that they sometimes agree with the statement. Receiving e-mails can be regarded as normal since they are not by them. It was revealed that they rarely do things such as looking at career-related pages, shopping online, sending e-mails during the course.

Table 6. Results regarding students' Cyberloafing status

\begin{tabular}{lcc}
\multicolumn{1}{c}{ Entertainment cyberloafing } & $\mathbf{X}$ & $\mathbf{S}$ \\
\hline $\begin{array}{l}\text { I browse sports-related websites from } \\
\text { my smartphone in lessons. }\end{array}$ & 2.2708 & 1.33913 \\
\hline $\begin{array}{l}\text { I play online games on my } \\
\text { smartphone during the lessons. }\end{array}$ & 2.2222 & 1.45056 \\
\hline $\begin{array}{l}\text { I download online games from my } \\
\text { smartphone in the lessons. }\end{array}$ & 1.9097 & 1.31113 \\
\hline General & $\mathbf{2 . 1 3 4 3}$ & $\mathbf{1 . 0 6 1 6 7}$ \\
\hline
\end{tabular}

It is seen in the findings obtained from the analysis that university students rarely use their mobile devices for entertainment purposes during the lessons. Students rarely visit sports websites and rarely download and play online games. According to these results, we can say that students do not use their mobile phones for entertainment purposes much during the lessons.

\section{The Difference between Female and Male Students} towards the Cyberloafing levels

To determine whether there is a change in the cyberloafing status of the students according to their gender, it was first examined whether the data showed a normal distribution. It was determined from the analysis that the data showed a normal distribution. After the appropriateness of the data was determined, the independent sample t-test analysis technique was used. The results obtained from the Independent sample t-test analysis are presented in the Table below.

Table 7. Results regarding Cyberloafing Status of Female and Male Students

\begin{tabular}{|c|c|c|c|c|c|c|}
\hline & $\mathbf{N}$ & Mean & SD & $\begin{array}{c}\text { Mean } \\
\text { differ } \\
\text { ence }\end{array}$ & $\mathbf{t}$ & $\mathbf{P}$ \\
\hline 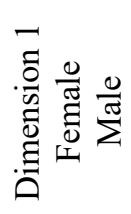 & $\begin{array}{l}92 \\
52\end{array}$ & $\begin{array}{l}2.76 \\
3.01\end{array}$ & $\begin{array}{l}1.12 \\
1.08\end{array}$ & -.253 & -1.31 & .190 \\
\hline 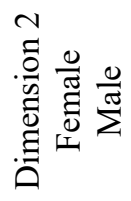 & $\begin{array}{l}92 \\
52\end{array}$ & $\begin{array}{l}2.37 \\
2.62\end{array}$ & $\begin{array}{l}1.02 \\
1.02\end{array}$ & -.256 & -1.44 & .151 \\
\hline 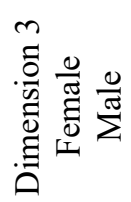 & $\begin{array}{l}92 \\
52\end{array}$ & $\begin{array}{l}1.95 \\
2.45\end{array}$ & $\begin{array}{l}1.05 \\
1.00\end{array}$ & -.502 & -2.79 & .006 \\
\hline
\end{tabular}

According to the results obtained from the analyzes conducted to determine whether there is a difference between the cyberloafing status of female and male students during the lesson, it was determined that there was no difference between the cyberloafing results and Interactive cyberloafing. However, there has been a slight difference when it comes to entertainment cyberloafing. It was determined that male students use their mobile devices more during the lessons. However, it is rare for males and females to use their mobile devices for entertainment purposes during lessons.

\section{Discussion and Conclusion}

Today, with the increase in the use of mobile devices, it has some difficulties that it has added to the learning process as well as making many contributions to the learning environment. One of them is the situation of students to use their mobile devices to make cyberloafing about extracurricular matters during the lesson. A study was carried out in the survey model to examine the cyberloafing of university students studying in the Turkish Republic of Northern Cyprus during the course with their mobile devices. 
According to the results obtained from the study, it is seen that a large proportion of university students use their mobile devices for at least three hours. Also, when the purposes of using mobile devices are examined, it has been determined that the most common use is to talk, message, and control social sharing accounts. Similarly, in the study conducted by Ataş and Çelik to determine the mobile device usage situations and purposes of 842 university students, it was determined that students spend 4 hours a day on the internet with their mobile devices on average. In the same study, it was determined that students used their mobile phones for messaging, chatting, and controlling their social media accounts [25]. These results show us that students spend a significant amount of time on the internet.

According to the results of the research, students sometimes do cyberloafing on their mobile devices during the lesson. The most cyberloafing activities that students perform for screening during the lessons are the activities of browsing about the subject they have learned in the lessons and chatting with their friends from applications such as messenger and Whatsapp. It has been determined that the cyberloafing that students mostly perform for interaction during the lesson is to control the web pages and e-mail accounts with videos, movies. Another result of the study is that they mostly perform cyberloafing for entertainment purposes, visiting web pages about sports.

When the cyberloafing status of university students was examined, it was found that male students made more cyberloafing than female students. It is seen that there is a significant difference especially regarding playing online games during the lesson. Similarly, in other studies in the literature, it has been determined that male students do more cyberloafing [20].

Schools, universities, and decision-makers have very important duties in this regard. Researchers should conduct studies by recognizing their cyberloafing situation and training needs throughout the country. This study can be used as a reference for determining the cyberloafing status of university students and organizing activities on the subject.

As with every study, this study also has some limitations. One of them is that only university students are included in the study. Studies can be conducted with younger individuals in future studies. Besides, the results obtained through qualitative studies can be examined in detail.

\section{References}

[1]. Lim, V. K., \& Chen, D. J. (2012). Cyberloafing at the workplace: gain or drain on work?. Behaviour \& Information Technology, 31(4), 343-353.

[2]. Gökçearslan, Ş., Uluyol, Ç., \& Şahin, S. (2018). Smartphone addiction, cyberloafing, stress and social support among university students: A path analysis. Children and Youth Services Review, 91, 4754.

[3]. Askew, K., Buckner, J. E., Taing, M. U., Ilie, A., Bauer, J. A., \& Coovert, M. D. (2014). Explaining cyberloafing: The role of the theory of planned behavior. Computers in Human Behavior, 36, 510519.

[4]. Anandarajan, M., Devine, P., \& Simmers, C. A. (2004). A Multidimensional Sealing Approach to Personal Web Usage in the Workplace. In Personal web usage in the workplace: A guide to effective human resources management (pp. 61-79). IGI Global.

[5]. Ünal, Ö. F., \& Tekdemir, S. (2015). Sanal Kaytarma: Bir Kamu Kurumunda Ampirik Bir Araştırma. Süleyman Demirel Üniversitesi Iktisadi ve Idari Bilimler Fakültesi Dergisi, 20(2), 95-118.

[6]. Gunay M. (2017). Sanal Kaytarma. Polatc1, S. \& Özyer, K., 21. Yüzyılda Örgütsel Davranış (257-277). Istanbul: BETA.

[7]. Mercado, B. K., Giordano, C., \& Dilchert, S. (2017). A meta-analytic investigation of cyberloafing Brittany K. Mercado, Casey Giordano, Stephan Dilchert. Career Development International, 22(5), 546-564. DOI: 10.1108/CDI-08-2017-0142

[8]. Knight, R. M. (2017). Academic cyberloafing: A study of perceptual and behavioral differences on inclass cyberloafing among undergraduate students. Retrieved from: http://hdl.handle.net/10342/6133 [accessed: 16 November 2020].

[9]. Kalaycı, E. (2010). Üniversite öğrencilerinin siber aylaklık davranışları ile öz düzenleme stratejileri arasındaki ilişkinin incelenmesi. Yayınlanmamış Yüksek Lisans Tezi, Ankara, Hacettepe Üniversitesi Fen Bilimleri Enstitüsü.

[10]. Coskun, B. K., \& Akar, I. (2020). Exploring the relationship between creativity and cyberloafing of prospective teachers. Thinking Skills and Creativity, 38, 100724.

[11]. Akbulut, Y., Dönmez, O., \& Dursun, Ö. Ö. (2017). Cyberloafing and social desirability bias among students and employees. Computers in Human Behavior, 72, 87-95.

[12]. Stoddart, S. R., (2016). The impact of cyberloafing and mindfulness on employee burnout. Doctoral dissertation. Wayne State University.

[13]. Coker, B. L. (2013). Workplace internet leisure browsing. Human Performance, 26(2), 114-125. 
[14]. Syrek, C. J., Kühnel, J., Vahle-Hinz, T., \& De Bloom, J. (2018). Share, like, twitter, and connect: Ecological momentary assessment to examine the relationship between non-work social media use at work and work engagement. Work \& Stress, 32(3), 209-227.

[15]. Wu, J., Mei, W., Liu, L., \& Ugrin, J. C. (2020). The bright and dark sides of social cyberloafing: Effects on employee mental health in China. Journal of Business Research, 112, 56-64.

[16]. McBride, J., Milligan, J., \& Nichols, J. (2006). Who's teaching the kids? Cyberslacking in the classroom. Journal of College and Character, 7(1).

[17]. Garrett, R. K., \& Danziger, J. N. (2008). On cyberslacking: Workplace status and personal Internet use at work. Cyber Psychology \& Behavior, 11(3), 287-292.

[18]. Ergün, E., \& Altun, A. (2012). Öğrenci gözüyle siber aylaklik ve nedenleri. Ĕgitim Teknolojisi Kuram ve Uygulama, 2(1), 36-53.

[19]. Gezgin, D. M., Arslantaş, T. K., \& Şumuer, E. (2018). Meslek Lisesi Öğrencilerinin Siber Aylaklık Düzeyinin Farklı Değişkenlere Göre İncelenmesi. Ege Ĕ̆itim Dergisi, 19(2), 408-424.

[20]. Keser, H., Kavuk, M., \& Numanoglu, G. (2016). The Relationship between Cyber-Loafing and Internet Addiction. Cypriot Journal of Educational Sciences, 11(1), 37-42.
[21]. Şenel, S., Günaydın, S., Sarıtaş, M. T., \& Çiğdem, H. (2019). Üniversite öğrencilerinin siber aylaklık seviyelerini yordayan faktörler. Kastamonu Eğitim Dergisi, 27(1), 95-105.

[22]. Korucu, A. T., \& Senem, K. A. R. A. (2019). Öğretmen Adaylarının Derslerde Akıllı Telefon Siber Aylaklık Düzeyleri İle Sanal Ortam Yalnızlık Düzeyleri Arasındaki İlişkinin İncelenmesi. Bilgi ve İletişim Teknolojileri Dergisi, 1(1), 41-56.

[23]. Polat, M. (2018). Derslerde akillı telefon siber aylaklığı ölçeği (DATSAÖ): Üniversite öğrencileri için bir ölçek uyarlama çalışması. Social Sciences Studies Journal (SSSJournal), 4(21), 3114-3127.

[24]. Minaz, A., \& Çetinkaya Bozkurt, Ö. (2017). Investigation of university students smartphone addiction levels and usage purposes in terms of different variables. Mehmet Akif Ersoy University Journal of Social Sciences Institute, 9(21), 268-286.

[25]. Ataş, A. H., \& Çelik, B. (2019). Smartphone use of university students: Patterns, purposes, and situations. Malaysian Online Journal of Educational Technology, 7(2), 54-70.

[26]. Yakob, R. (2009). Grown up digital: how the net generation is changing your world. International Journal of Advertising, 28(1), 182-184. 